\title{
Tickborne Relapsing Fever, Jerusalem, Israel, 2004-2018
}

\author{
Saar Hashavya, ${ }^{1}$ Itai Gross, ${ }^{1}$ Matan Gross, Noa Hurvitz, Giora Weiser, Violeta Temper, Orli Megged
}

To compare tickborne relapsing fever (TBRF) in children and adults in Jerusalem, Israel, we collected data from the medical records of all 92 patients with TBRF during 20042018. The 30 children with TBRF had more episodes of fever and lower inflammatory markers than adult patients.

Tickborne relapsing fever (TBRF), caused by Bor1 relia species bacteria, is transmitted by soft ticks of the genus Ornithodoros $(1,2)$. TBRF is characterized by recurring episodes of fever often accompanied by headache, nausea, vomiting, dyspnea, and joint pain (3). Although highly endemic to certain regions of the world, such as West Africa (4), Iran (5), and Morocco (6), TBRF occurs worldwide $(7,8)$.

In Israel, TBRF is endemic and is caused by $B$. persica, which is transmitted to humans by the $O$. tholozani soft tick $(9,10)$. TBRF remains challenging to diagnose because of its nonspecific symptoms. To compare TBRF in children and adults, we assessed anamnestic, clinical, and laboratory parameters of persons with TBRF at 3 emergency departments (EDs) in Jerusalem, Israel.

\section{The Study}

We reviewed the computerized databases of Hadassah Ein-Kerem Medical Center, Hadassah MountScopus Medical Center, and Shaare Zedek Medical Center for all patients who had a discharge diagnosis of borreliosis (International Classification of Diseases, 10th Revision, code A69.2) during 2004-2018. These hospitals treated most patients in Jerusalem. All patients in the study with thick or thin blood film were positive for spirochetes or had positive results from a $B$. persica homemade Flagellin gene CR (10). For thin blood film, $1 \mu \mathrm{L}$ was used, and for thick blood film, $10 \mu \mathrm{L}$. For both films, we used Giemza stain to show Borrelia. We completed thin and thick films for all

Author affiliations: Hadassah Medical Center, Jerusalem, Israel

(S. Hashavya, I. Gross, M. Gross, V. Temper); Hebrew University, Ein Kerem, Israel (N. Hurvitz); Shaare Zedek Medical Center, Jerusalem (G. Weiser, O. Megged)

DOI: https://doi.org/10.3201/eid2610.181988 patients with clinically suspected borreliosis. PCR was also routinely performed except for sporadic cases, for which insufficient blood remained the tube after complete blood count and films were conducted.

We defined relapse as recurrence of symptoms and positive laboratory results, after completion of treatment and without new exposures. The information collected comprised demographics (age, ethnicity, and sex); history (visits to caves, exposure to tick bites); duration of fever and number of relapses of fever; incubation period; physical examination findings; laboratory results; and hospitalization data, including length, referral to intensive care unit, and drug treatment. To determine the characteristics of TBRF in children, we compared children $<18$ years of age with adults.

The Hadassah medical center institutional review board approved this study and provided a consent waiver (approval no. 0345-18-HMO) We used $\chi^{2}$ tests to compare proportions and Student $t$ and MannWhitney $U$ tests to compare continuous nonparametric variables, and we considered $p<0.05$ significant. We conducted statistical analysis using SPSS Statistics 21.0 (IBM Inc., https:/ / www.ibm.com).

Illnesses of 92 patients with blood film positive for spirochete or a positive Borrelia persica PCR met the case definition (Table). Forty $(43 \%)$ patients were admitted to the hospital; the rest were discharged from the ED. The average age $( \pm \mathrm{SD})$ was $21.3( \pm 10.9)$ years; $30(33 \%)$ patients were children $<18$ years of age. Seventy-five (82\%) patients were male (Figure).

Children had an average of 1.71 (95\% CI 1.22-2.21) relapses of fever, whereas adults had 0.67 (95\% CI $0.5-0.83$ ) relapses $(\mathrm{p}<0.01) ; 40 \%$ of children had $>1$ relapse. The 2 groups (adults and children) did not differ significantly in terms of need for intensive care unit or hospital admission. Recent cave visits were reported for nearly $83 \%$ of patients. Although the difference was not significant, gastrointestinal symptoms (abdominal pain, vomiting, and diarrhea) occurred more often among children than adults $(53.3 \%$ vs. $35.5 ; \mathrm{p}=0.1)$.

${ }^{1}$ These authors contributed equally to this article. 
A tick bite mark was the most common finding on physical examination $(36.7 \%$ of children vs. $27.4 \%$ of adults), followed by organomegaly $(16.7 \%$ vs. $19.4 \%)$. Although the difference was not significant, neurologic signs on physical examination were more common among children than adults (13.3\% vs. $3.2 \%)$.

Platelet counts were higher in children than in adults, and fewer children had thrombocytopenia (Table). C-reactive protein levels were significantly

\begin{tabular}{|c|c|c|c|c|}
\hline 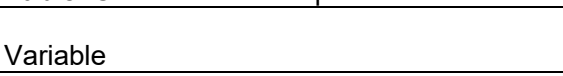 & $\begin{array}{c}\text { Children and } \\
\text { adolescents, } n=30\end{array}$ & Adults, $n=62$ & Total, $\mathrm{n}=92$ & $p$ value \\
\hline $\begin{array}{l}\text { Age, y† } \\
\text { Mean }(95 \% \mathrm{Cl}) \\
\text { Median (range) }\end{array}$ & $\begin{array}{c}11.65(10.3-13.1) \\
12(3-18)\end{array}$ & $\begin{array}{c}25.97(23.5-28.5) \\
22.5(19-70)\end{array}$ & $\begin{array}{c}21.3(21.23-21.37) \\
19(3-70)\end{array}$ & $<0.01$ \\
\hline $\begin{array}{l}\text { Sex, no. }(\%) \\
\mathrm{M} \\
\mathrm{F}\end{array}$ & $\begin{array}{l}21(70.0) \\
9(30)\end{array}$ & $\begin{array}{l}54(87.1) \\
8(12.9)\end{array}$ & $\begin{array}{l}75(81.5) \\
17(18.5)\end{array}$ & 0.09 \\
\hline $\begin{array}{l}\text { Hospitalization, d } \\
\text { Mean }(95 \% \mathrm{Cl}) \\
\text { Median (range) } \\
\end{array}$ & $\begin{array}{c}2.57(1.82-3.32) \\
2 \\
\end{array}$ & $\begin{array}{c}2.66(2.31-3.01) \\
2 \\
\end{array}$ & $\begin{array}{c}2.63(2.62-2.64) \\
2 \\
\end{array}$ & 0.39 \\
\hline $\begin{array}{l}\text { Mean no. ED visits }(95 \% \mathrm{Cl}) \\
\text { ICU admission, no. (\%) } \\
\text { Treatment with doxycycline, no. }(\%) \\
\text { Jarisch-Herxheimer reaction, no. (\%) }\end{array}$ & $\begin{array}{c}1.26(1.12-1.4) \\
0 \\
25(83.3) \\
4(13.3) \\
\end{array}$ & $\begin{array}{c}1.21(0.99-1.43) \\
2(3.2) \\
61(98.4) \\
15(24.19)\end{array}$ & $\begin{array}{c}1.231(1.12-1.34) \\
2(2.2) \\
86(93.5) \\
19(20.7)\end{array}$ & $\begin{array}{c}0.6 \\
0.45 \\
0.09 \\
0.35\end{array}$ \\
\hline $\begin{array}{l}\text { Exposure history } \\
\text { Cave visits, no. (\%) } \\
\text { Known tick bite, no. (\%) } \\
\text { Mean incubation period, d, }(95 \% \mathrm{Cl})\end{array}$ & $\begin{array}{c}24(80.0) \\
9(30.0) \\
8.41(6.22-10.6)\end{array}$ & $\begin{array}{c}52(83.9) \\
21(33.8) \\
9.4(7.06-11.74)\end{array}$ & $\begin{array}{c}76(82.6) \\
30(32.6) \\
9.1(9.05-9.15)\end{array}$ & $\begin{array}{l}0.82 \\
0.88 \\
0.61\end{array}$ \\
\hline $\begin{array}{l}\text { Fever } \\
\text { Mean duration before ED visit, d (95\% Cl) } \\
>1 \text { Relapse of fever, no. (\%) } \\
\text { No. fever episodes at diagnosis } \\
1 \\
2 \\
3 \\
4 \\
5 \\
\text { Missing information }\end{array}$ & $\begin{array}{c}12.4(8.53-16.27) \\
12(40.0)\end{array}$ & $\begin{array}{c}10(7.31-12.7) \\
\quad 7(11.3)\end{array}$ & $\begin{array}{c}9.76(9.69-9.85) \\
19(20.6)\end{array}$ & $\begin{array}{c}0.13 \\
<0.01\end{array}$ \\
\hline $\begin{array}{l}\text { Signs and symptoms, no. (\%) } \\
\text { Gastrointestinal } \\
\text { Respiratory } \\
\text { Myalgia } \\
\text { Malaise } \\
\text { CNS symptoms } \\
\text { History of shivering } \\
\text { Organomegaly } \\
\text { Rash } \\
\text { CNS signs } \\
\text { Bite mark, no. (\%) }\end{array}$ & $\begin{array}{l}16(53.3) \\
1(3.3) \\
8(26.7) \\
11(36.7) \\
19(63.3) \\
6(20.0) \\
5(16.7) \\
6(20.0) \\
4(13.3) \\
11(36.7)\end{array}$ & $\begin{aligned} & 22(35.5) \\
& 5(8.1) \\
& 22(35.5) \\
& 24(38.7) \\
& 32(51.6) \\
& 19(30.6) \\
& 12(19.4) \\
& 7(11.3) \\
& 2(3.2) \\
& 17(27.4)\end{aligned}$ & $\begin{aligned} 38 & (41.3) \\
6 & (6.5) \\
30 & (32.6) \\
35 & (38.0) \\
51 & (55.4) \\
25 & (27.2) \\
17 & (18.5) \\
13 & (14.1) \\
6 & (6.5) \\
28 & (30.4)\end{aligned}$ & $\begin{array}{l}0.1 \\
0.39 \\
0.4 \\
0.85 \\
0.29 \\
0.29 \\
0.76 \\
0.26 \\
0.07 \\
0.36\end{array}$ \\
\hline 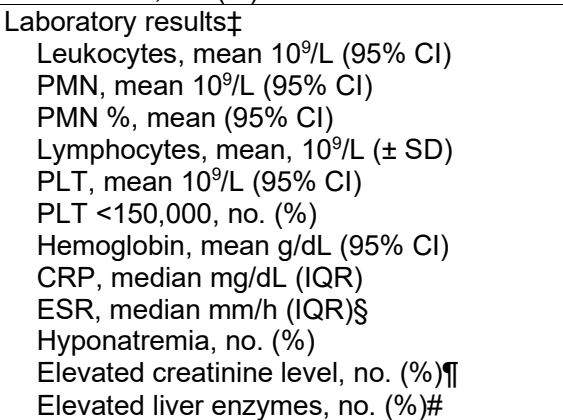 & $\begin{array}{c}8.65(7.71-9.59) \\
5.16(4.22-6.1) \\
0.58(0.51-0.64) \\
1.85(1.39-2.31) \\
174.2(146-203) \\
12(40) \\
11.98(11.3-12.7) \\
7.93(6.35-9.5) \\
53.92(40.76-67.09) \\
9(30.0) \\
2(6.7) \\
0\end{array}$ & $\begin{array}{c}9.74(7.32-12.16) \\
7.12(5.34-8.89) \\
0.72(0.54-0.9) \\
1.23(0.92-1.54) \\
136.93(102.85-171.02) \\
35(56.5) \\
13.35(10.03-16.67) \\
16.87(12.67-21.07) \\
53.96(40.53-67.39) \\
17(27.4) \\
13(21) \\
8(12.9)\end{array}$ & $\begin{array}{c}9.37(9.35-9.39) \\
6.45(9.43-6.47) \\
0.674(0.67-0.68) \\
1.442(1.44-1.45) \\
149.64(149.13-150.15) \\
47(51.1) \\
12.88(12.87-12.89) \\
12.2(5.5-17.8) \\
50(30-75) \\
26(28.2) \\
15(16.3) \\
8(8.7)\end{array}$ & $\begin{array}{c}0.13 \\
<0.01 \\
<0.01 \\
<0.01 \\
0.04 \\
0.2 \\
<0.01 \\
<0.01 \\
0.99 \\
0.8 \\
0.08 \\
0.04\end{array}$ \\
\hline $\begin{array}{l}\text { †Number of persons in each group were as follows } \\
46-70 \text { y: } 5 \text {. } \\
\text { †Reference ranges: Platelets }\left(10^{9} / \mathrm{L}\right), 150,000-400 \\
\text { §Children, } n=13 \text {; adults, } n=26 \text {. }\end{array}$ & -reactive protein (mg & $<0.5 ; \operatorname{ESR}(\mathrm{mm} / \mathrm{h})<20$ & ICU, intensive ca & nit; IQR, \\
\hline
\end{tabular}




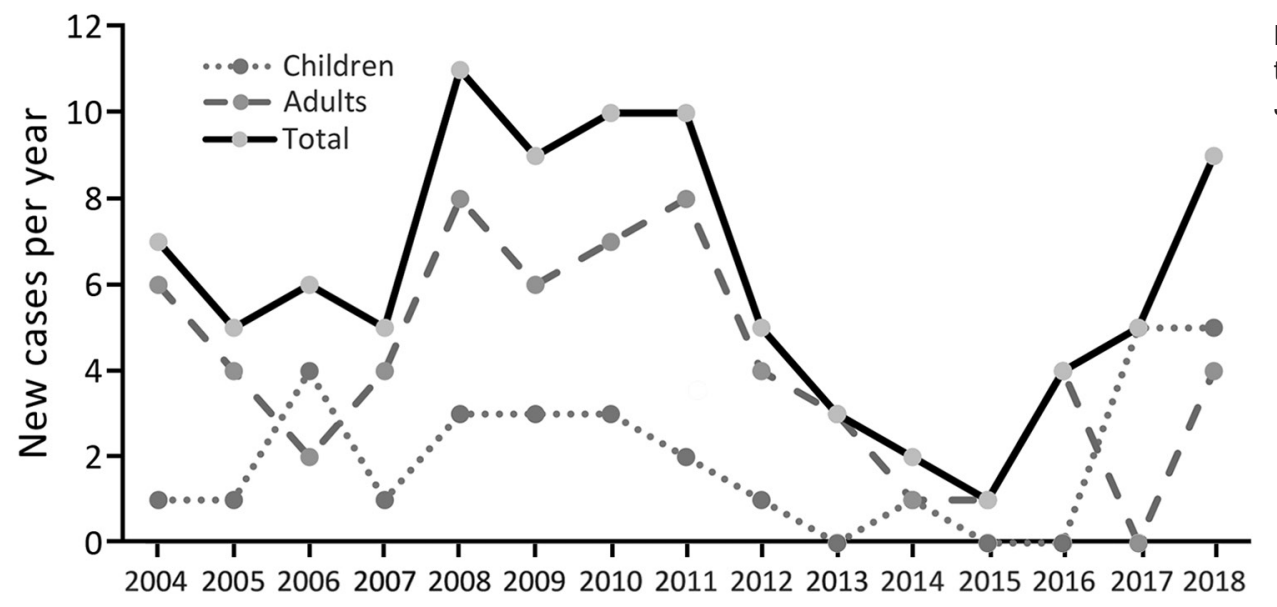

Figure. Annual number of new tickborne relapsing fever cases, Jerusalem, Israel.

lower in children; erythrocyte sedimentation rate and total leukocyte count did not differ significantly between children and adults. The distribution of leukocyte counts differed significantly between the 2 groups: children had a lower neutrophil count and higher lymphocyte count. Children also had a lower percentage of elevated liver enzymes ( $0 \%$ vs. $12.9 \%$; $\mathrm{p}=0.04$ ).

Twenty-six children $(83 \%)$ were treated with doxycycline; 3 received azithromycin $(10 \mathrm{mg} / \mathrm{kg} / \mathrm{d})$; and 2 received amoxicillin $(50 \mathrm{mg} / \mathrm{kg} / \mathrm{d}$, divided into 3 daily doses). By contrast, 61 adults (98\%) were treated with doxycycline (1 adult treated with ceftriaxone [2 g/day] was discharged with doxycycline). Children treated with doxycycline received $4.4 \mathrm{mg} /$ $\mathrm{kg}$ / day, divided into 2 daily doses, and adults received $100 \mathrm{mg} 2$ times/day. One adult treated with doxycycline had 2 relapses, was re-treated with doxycycline, and recovered fully. All the patients treated with azithromycin recovered. However, illness relapsed in both children treated with amoxicillin; 1 was subsequently treated with azithromycin, and the other was treated with intravenous penicillin and intravenous ceftriaxone and discharged with azithromycin. A Jarisch-Herxheimer reaction occurred in nearly $21 \%$ of all patients (Table). All patients fully recovered.

\section{Conclusions}

TBRF in children was characterized by more relapsing febrile episodes before medical advice was sought. One possible explanation is that febrile illnesses are more common in children than in adults, which may delay the decision to take a child to the ED or to begin a more thorough investigation in the ED. Gastrointestinal symptoms were reported more commonly in children and were the second most common symptom after fever. Findings of children from Iran who had TBRF were similar (5). In our study, no meningeal involvement occurred in the older group of adults; however, 1 child had suspected meningitis ( 21 cells in his cerebrospinal fluid with negative PCR). The expected rate is $4 \%$ in adults but is rare in children $(5,7)$.

In adults, we found increased levels of C-reactive protein, relatively higher leukocyte counts (in reference to age norms), and higher neutrophil counts than in children. The difference in neutrophil count could be only partially explained by the difference in age-adjusted norms because only 10 children were $<10$ years. These findings, in addition to longer duration of fever and more relapses that did not require hospitalization, might suggest a milder course of illness in children. A possible explanation is that signs and symptoms tend to appear later in the course of the disease, and TBRF symptoms tend to be milder during relapses (12).

The 2 children treated with amoxicillin experienced relapses, whereas only 1 patient treated with doxycycline and none of the patients treated with azithromycin had relapse. Use of doxycycline remains controversial, despite recent reports showing its safety in children (13). Consistent with the literature, our findings support the safety and efficaciousness of erythromycin as an alternative treatment for children with TBRF $(5,14)$.

This study has several limitations. Because of its retrospective design, all parameters were data retrieved from medical charts. The study's small sample size, especially the number of children, hindered identification of other subtle differences between children and adults. Nevertheless, this study provides data on the differences between the manifestations of TBRF in children and adults. 


\section{About the Author}

Dr. Hashavia is the director of Pediatric Emergency Medicine Hadassah Hospital Ein Kerem. His primary research interests include clinical assessment of infectious disease in pediatric emergency medicine, pediatric trauma, and pediatric emergency medicine. Dr. Gross works in the Department of Pediatric Emergency Medicine, Hadassah Medical Center. His primary research interests include emergency medicine, pediatric trauma, and pediatric infectious diseases.

\section{References}

1. Nicholson FD. Tick fever in Palestine. BMJ. 1919;2:811. https://doi.org/10.1136/bmj.2.3077.811

2. Sidi G, Davidovitch N, Balicer RD, Anis E, Grotto I, Schwartz E. Tickborne relapsing fever in Israel. Emerg Infect Dis. 2005;11:1784-6. https://doi.org/10.3201/eid1111.050521

3. Assous MV, Wilamowski A. Relapsing fever borreliosis in Eurasia - forgotten, but certainly not gone! Clin Microbiol Infect. 2009;15:407-14. https://doi.org/10.1111/ j.1469-0691.2009.02767.x

4. Trape JF, Diatta G, Arnathau C, Bitam I, Sarih M, Belghyti D, et al. The epidemiology and geographic distribution of relapsing fever borreliosis in West and North Africa, with a review of the Ornithodoros erraticus complex (Acari: Ixodida). [Erratum in: PLoS One. 2014;9(1).] PLoS One. 2013;8:e78473. https://doi.org/10.1371/journal.pone.0078473

5. Ayazi P, Mahyar A, Oveisi S, Esmailzadehha N, Nooroozi S Tick-borne relapsing fever in children in the north-west of Iran, Qazvin. Prague Med Rep. 2015;116:193-202. https:// doi.org/10.14712/23362936.2015.58

6. Diatta G, Souidi Y, Granjon L, Arnathau C, Durand P, Chauvancy G, et al. Epidemiology of tick-borne borreliosis in Morocco. PLoS Negl Trop Dis. 2012;6:e1810. https:// doi.org/10.1371/journal.pntd.0001810

7. Castilla-Guerra L, Marín-Martín J, Colmenero-Camacho MA. Tick-borne relapsing fever, southern Spain, 2004-2015. Emerg Infect Dis. 2016;22:2217-9.

8. Dworkin MS, Shoemaker PC, Fritz CL, Dowell ME, Anderson DE Jr. The epidemiology of tick-borne relapsing fever in the United States. Am J Trop Med Hyg. 2002;66: 753-8. https://doi.org/10.4269/ajtmh.2002.66.753

9. Parola P, Raoult D. Ticks and tickborne bacterial diseases in humans: an emerging infectious threat. Clin Infect Dis. 2001;32:897-928 https:/ / academic.oup.com/cid/ article/32/6/897/306927. https://doi.org/10.1086/319347

10. Assous MV, Wilamowski A, Bercovier H, Marva E. Molecular characterization of tickborne relapsing fever Borrelia, Israel. Emerg Infect Dis. 2006;12:1740-3. https:// doi.org/10.3201/eid1211.060715

11. Kahl L, Hughes H. The Harriet Lane handbook. Mobile medicine series. 21st ed. Philadelphia: Elsevier; 2017.

12. Brady MT, Jackson MA, Long SS. Redbook 2018 [cited 2008 Dec 26].

13. Gaillard T, Briolant S, Madamet M, Pradines B. The end of a dogma: the safety of doxycycline use in young children for malaria treatment. Malar J. 2017;16:148. https:/ / doi.org/10.1186/s12936-017-1797-9

14. Le CT. Tick-borne relapsing fever in children. Pediatrics. 1980;66:963-6.

Address for correspondence: Itai Gross, Hadassah Medical Center, Ein Karem, 91120, Jerusalem, Israel; email: itaigross@gmail.com

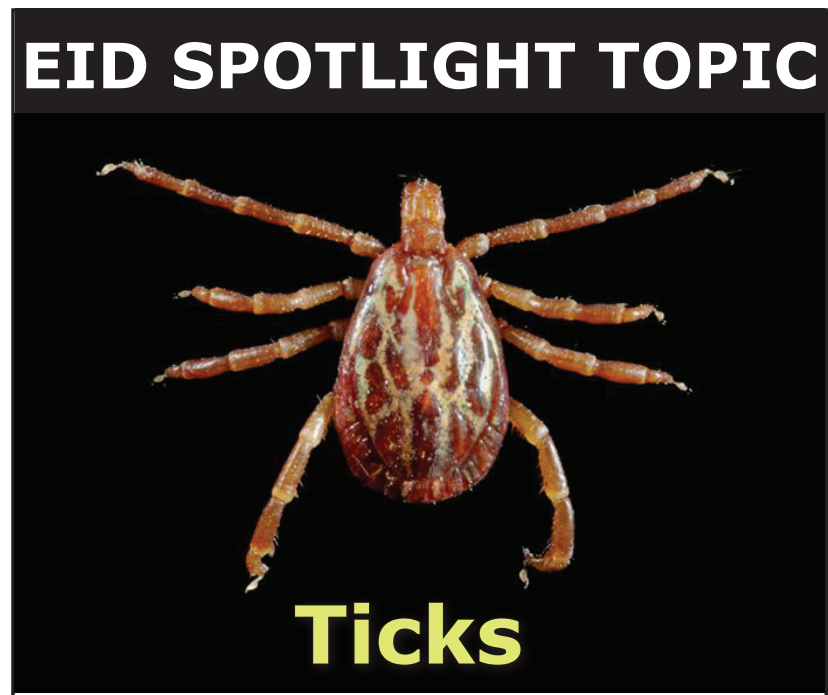

Ticks transmit a variety of different pathogens including bacteria, protozoa, and viruses which can produce serious and even fatal disease in humans and animals. Tens of thousands of cases of tickborne disease are reported each year, including Lyme disease. See the EID Lyme Disease Spotlight. Lyme disease is the most well-known tickborne disease. However, other tickborne illnesses such as Rocky Mountain spotted fever, tularemia, babesiosis, and ehrlichiosis also contribute to severe morbidity and more mortality each year.

Symptoms of tickborne disease are highly variable, but most include sudden onset of fever, headache, malaise, and sometimes rash. If left untreated, some of these diseases can be rapidly fatal.
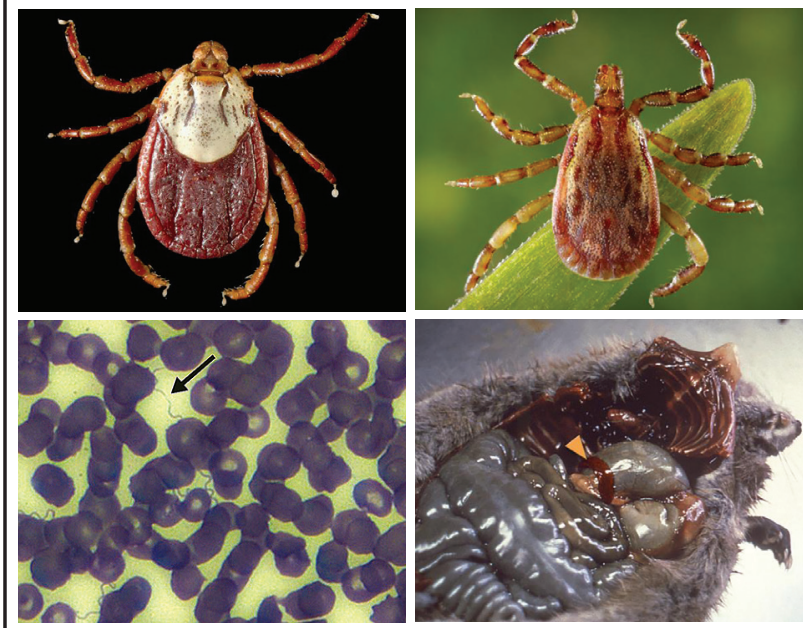

\section{https://wwwnc.cdc.gov/eid/ page/tick-spotlight}

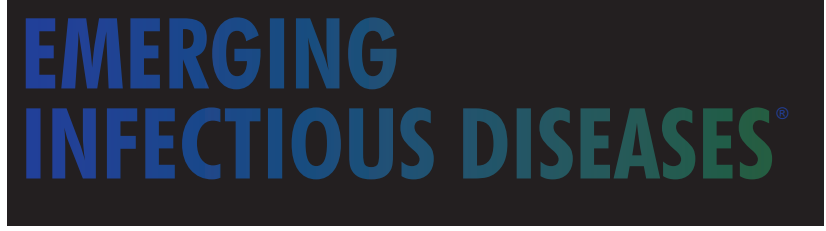

